\title{
Understanding the effects of early degradation on isotopic tracers: implications for sediment source attribution using compound-specific isotope analysis (CSIA)
}

\author{
Pranav Hirave $^{1}$, Guido L. B. Wiesenberg ${ }^{2}$, Axel Birkholz ${ }^{1}$, and Christine Alewell ${ }^{1}$ \\ ${ }^{1}$ Environmental Geosciences, Department of Environmental Sciences, University of Basel, Basel, Switzerland \\ ${ }^{2}$ Department of Geography, University of Zurich, Zurich, Switzerland
}

Correspondence: Pranav Hirave (pranav.hirave@unibas.ch)

Received: 25 May 2019 - Discussion started: 4 June 2019

Revised: 21 January 2020 - Accepted: 18 March 2020 - Published: 20 April 2020

\begin{abstract}
Application of compound-specific isotope analysis (CSIA) in sediment fingerprinting source apportionment studies is becoming more frequent, as it can potentially provide robust land-use-based source attribution of suspended sediments in freshwater and marine systems. Isotopic tracers such as $\delta^{13} \mathrm{C}$ values of vegetation-derived organic compounds are considered to be suitable for the CSIA-based fingerprinting method. However, a rigorous evaluation of tracer conservativeness in terms of the stability of isotopic signature during detachment and transport of soil during erosion is essential for the suitability of the method. With the aim to identify potential fractionation and shifts in tracer signature during early degradation of organic matter in surface soils, we measured concentrations and $\delta^{13} \mathrm{C}$ values of long-chain fatty acids and $n$-alkanes from fresh plant biomass (as vegetation is a direct source of these compounds to the soils), degraded organic horizon (O horizon), and mineral soil (A horizon) from various forest types with different humus forms (five sites). The bulk $\delta^{13} \mathrm{C}$ values showed continuous ${ }^{13} \mathrm{C}$ enrichment through the degradation stages from fresh plant material to the $\mathrm{O}$ and $\mathrm{A}$ horizons, ranging between $3.5 \%$ and $5.6 \%$. Compound-specific $\delta^{13} \mathrm{C}$ values showed a general ${ }^{13} \mathrm{C}$ enrichment for both long-chain fatty acids (up to $5 \%$ ) and $n$-alkanes (up to $3.9 \%$ ) from fresh plant biomass to the $\mathrm{O}$ horizon overlying the A horizon. However, only slight or no further changes occurred from the $\mathrm{O}$ to the A horizon. We also compared compound-specific $\delta^{13} \mathrm{C}$ values between two soil particle size classes $(<2 \mathrm{~mm}$ and $<63 \mu \mathrm{m})$ from four sites and found no significant differences of tracer values between them, with even less fractionation for the long-chain
\end{abstract}

$n$-alkanes within the soil particle fractions. This points to the conclusion that sampling and analysing bulk soil material might be valid for the isotopic tracer applications. We further conclude that our results support the suitability of studied isotopic tracers as a representative source soil signature in the CSIA-based sediment source attribution, as they demonstrated necessary stability in the plant-soil system during organic matter degradation.

\section{Introduction}

Soils play a key role in the storage of organic carbon in terrestrial ecosystems (Schmidt et al., 2011; Scharlemann et al., 2014). Plant lipids constitute a major part of soil organic matter (OM) and can also be used as biomarkers for tracing plant-derived OM in soil. These plant lipids are continuously transferred into the soil after their production, through litter deposition and abrasion of cuticular waxes (Glaser, 2005; Jansen and Wiesenberg, 2017). Compound-specific isotope analysis (CSIA) of lipid constituents such as long-chain fatty acids and $n$-alkanes has been routinely used as a valuable tool to infer soil OM source and turnover (Wiesenberg et al., 2004; Zocatelli et al., 2012), reconstruct paleoenvironments and paleovegetation (Glaser and Zech, 2005; Eglinton and Eglinton, 2008), and fingerprint sediment-bound OM sources in freshwater and marine environments (Canuel et al., 1997; Galy et al., 2011). As freshwater ecosystems are currently under the threat of high sediment input due to the intensification of anthropogenic activities and associated land-use 
changes, the CSIA technique has recently been adopted for improved quantification of the sediment sources from different land uses (Gibbs, 2008).

Sediment fingerprinting based on CSIA utilizes the vegetation-specific isotopic signatures of the lipid biomarkers to discriminate the sediment sources by the fraction attributable to the major land uses present in the catchment. In particular, carbon isotopic composition $\left(\delta^{13} \mathrm{C}\right.$ values $)$ of individual long-chain fatty acids (Gibbs, 2008; Blake et al., 2012; Hancock and Revill, 2013; Alewell et al., 2016; Brandt et al., 2016; Mabit et al., 2018), long-chain $n$-alkanes (Seki et al., 2010; Cooper et al., 2015; Chen et al., 2016), and plant-family-specific biomarkers (e.g. triterpenyl acetates produced by Asteraceae) (Lavrieux et al., 2019) has been used to trace freshwater sediments (Lavrieux et al., 2019). The CSIA technique is also complemented by the use of molecular proxies based on the concentration of these compounds such as the average chain length (ACL) values and carbon preference index (CPI) (Cooper et al., 2015). An overview of the current understanding and progress on CSIAbased sediment source attribution has been summarized by Reiffarth et al. (2016) and Upadhayay et al. (2017).

The vegetation specificity in isotopic composition of plant lipid components is an important property for CSIA-based sediment source attribution. This specificity generally depends on biological (i.e. photosynthesis) and environmental factors (i.e. water stress) that play a role during lipid synthesis and are subsequently transferred to the soil. Huang et al. (1997) reported long-term degradation and diagenesis processes did not result in the changes of carbon isotope composition of $n$-alkanes in agricultural soils after their transfer from fresh plant material. The $\delta^{13} \mathrm{C}$ signature of organic compounds does not change by volatilization, dilution, dispersion, and sorption (Blessing et al., 2008, and references therein). However, large uncertainty is also observed in the isotopic stability of these tracers in the plant-soil systems (Chikaraishi and Naraoka, 2006; Nguyen Tu et al., 2011). Some studies report an increase of several per mil in $n$-alkane $\delta^{13} \mathrm{C}$ values of the soils compared to the dominant higher terrestrial plants (Ficken et al., 1998; Nguyen Tu et al., 2004; Wiesenberg et al., 2004; Griepentrog et al., 2016). Hence the effects of early degradation on these plant-derived chemical assemblages across the soil horizons, in terms of their carbon isotope ratios and molecular distributions, need to be understood in greater detail. The degradation stage in the surface soils at which the tracer signature becomes stable and shows no further changes needs to be identified, not only for a reliable identification of source signature for the CSIA-based sediment fingerprinting technique, but also for an assessment of the relative stability of the isotopic signatures during detachment and transport of sediments. Our approach is to compare the original $\mathrm{C}$ isotopic signature from fresh plant material to the OM from the organic horizons and upper mineral soil horizon (i.e. increasing degradation stages along the organic horizons - topsoil profile). Also, it has been shown that within the soil particle size fractions and density fractions, the stability and composition of the tracer signal may change (Cayet and Lichtfouse, 2001; Quénéa et al., 2006; Griepentrog et al., 2016). In previous CSIA-based fingerprinting studies, the silt-clay fraction $(<63 \mu \mathrm{m})$ or $<100 \mu \mathrm{m}$ fraction has been chosen to extract the representative source signature (Gibbs, 2008; Blake et al., 2012; Hancock and Revill, 2013; Cooper et al., 2015). The bulk soil fraction $(<2 \mathrm{~mm})$ has also been used (Alewell et al., 2016).

We measured carbon isotopic composition and concentration of long-chain fatty acids and $n$-alkanes from fresh leaves, needles, mosses, degraded organic horizons, and mineral soil (Oi-Oe-Oa-A horizons) from various forest types with different humus forms, in order to (1) understand the effect of early degradation on the isotopic tracer signals employed in the CSIA-based sediment fingerprinting technique and (2) compare the two biomarker classes in terms of their $\delta^{13} \mathrm{C}$ values and molecular distribution in the plant-soil system for potential suitability as a representative source soil signature for sediment fingerprinting. We also analysed the compound-specific $\delta^{13} \mathrm{C}$ values from two soil particle size fractions $(<2 \mathrm{~mm}$ and $<63 \mu \mathrm{m}$ ) to (3) understand the soil particle-size-dependent isotopic fractionation and its implication for CSIA-based sediment source attribution.

\section{Materials and methods}

\subsection{Study area}

For studying the degradation effect on the vegetation-specific tracers, five sampling sites were selected (Fig. 1) of which two are in the Southern Black Forest (Germany), two in the Lake Baldegg catchment (Switzerland), and one in the Upper Sûre Lake catchment (Luxembourg) (Table 1). The broadleaved forest site in the Southern Black Forest (site 1; $\mathrm{BF}_{\text {beech }}$ ) was mainly stocked with beech (Fagus sylvatica), under which a moder-type (duff mull) humus with clearly separable Oi (undecomposed OM) and Oe (partly decomposed $\mathrm{OM}$ ) horizons, but a diffused boundary between the $\mathrm{O}$ and $\mathrm{A}$ horizons, has developed due to the absence of a separate Oa (decomposed OM, humus layer) horizon. The second site in the Southern Black Forest is a coniferous forest where the sole tree species is spruce (Picea abies, site 2a; $\mathrm{BF}_{\text {spruce }}$ ) and a thick cover of moss (Sphagnum quinquefarium, site $\left.2 \mathrm{~b} ; \mathrm{BF}_{\text {moss }}\right)$ is growing under very acidic conditions $(\mathrm{pH} \sim 3)$ characterized by the development of raw humus with an easily separable sequence of $\mathrm{Oi}-\mathrm{Oe}-\mathrm{Oa}$ and A horizons. One of the two sites in the Lake Baldegg catchment has mull-type humus with a thin Oi layer on top of the A layer (Site $\left.4 ; \mathrm{LB}_{\text {spruce }}\right)$. The mixed-forest site in the Upper Sûre Lake catchment has oak (Quercus robur) and spruce (Picea abies) cover with moder-type humus (site 5; $\mathrm{LX}_{\text {mixed }}$ ). All sampling sites have acidic soils with $\mathrm{pH}$ values in the range of 3-4.2. As we are aware that a range of soil $\mathrm{pH}$ values 


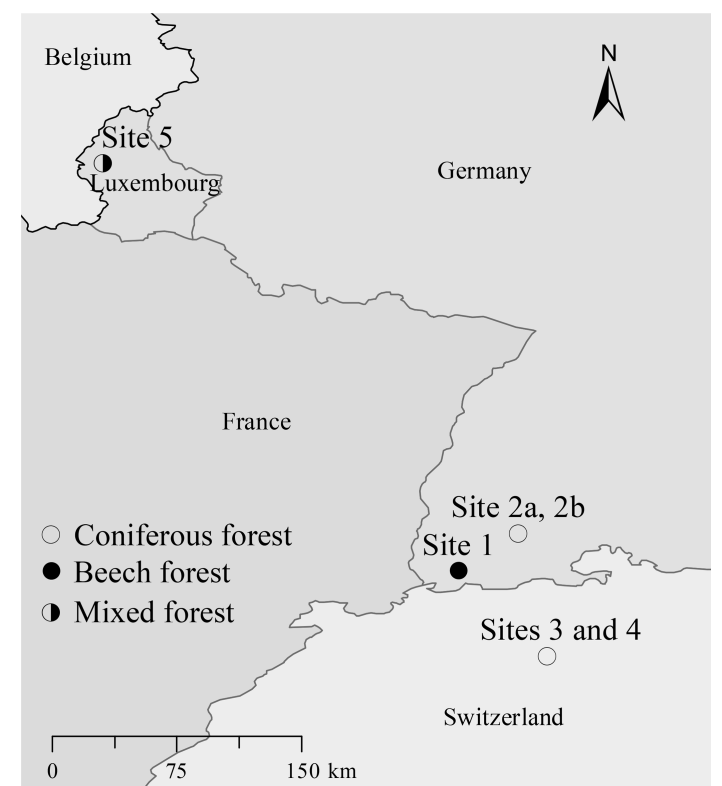

Figure 1. Map of all sampling sites.

might have been preferable, fully developed organic horizons are not found in slightly acidic or alkaline soils.

\subsection{Sampling}

Fresh leaves, needles, and mosses were collected in autumn. Multiple leaves and needles (15-20) from different directions at ca. $3 \mathrm{~m}$ above ground were collected from an individual tree and mixed to form a sample of fresh material. The $\mathrm{O}$ horizon was sampled and subhorizons within it were separated according to the humus form observed. The underlying A horizon was sampled to a maximum depth of $5 \mathrm{~cm}$. Each sample was formed from a composite mixture of three subsamples taken at a distance of ca. $1 \mathrm{~m}$ from each other.

\subsection{Sample preparation and bulk isotope analysis}

Collected samples were oven-dried at $40^{\circ} \mathrm{C}$ for $72 \mathrm{~h}$. Soils were dry sieved to a particle size $<2 \mathrm{~mm}$ and macroscopic plant remains and stones were removed with tweezers. All the samples were roughly ground with a mortar and pestle. An aliquot of ground samples was finely powdered with a ball mill (Retsch MM 400, Retsch GmbH, Haan, Germany) for $90 \mathrm{~s}$ at a frequency of $24 \mathrm{~s} \mathrm{~min}^{-1}$ for analysis of bulk carbon concentration and isotopic $\left(\delta^{13} \mathrm{C}\right)$ composition. Powdered samples were weighed in tin capsules, and subsequently stable carbon isotope ratios $\left(\delta^{13} \mathrm{C}_{\text {bulk }}\right)$ and $\mathrm{C}$ content were measured with an elemental analyser coupled to an isotope ratio mass spectrometer (EA-IRMS) (Sercon Integra2, Sercon Ltd., Crewe, UK). The carbon isotope values of samples are reported in a delta notation relative to the Vienna Peedee Belemnite (V-PDB) standard. The instrumental standard deviation is lower than $0.1 \%$ for $\delta^{13} \mathrm{C}$.

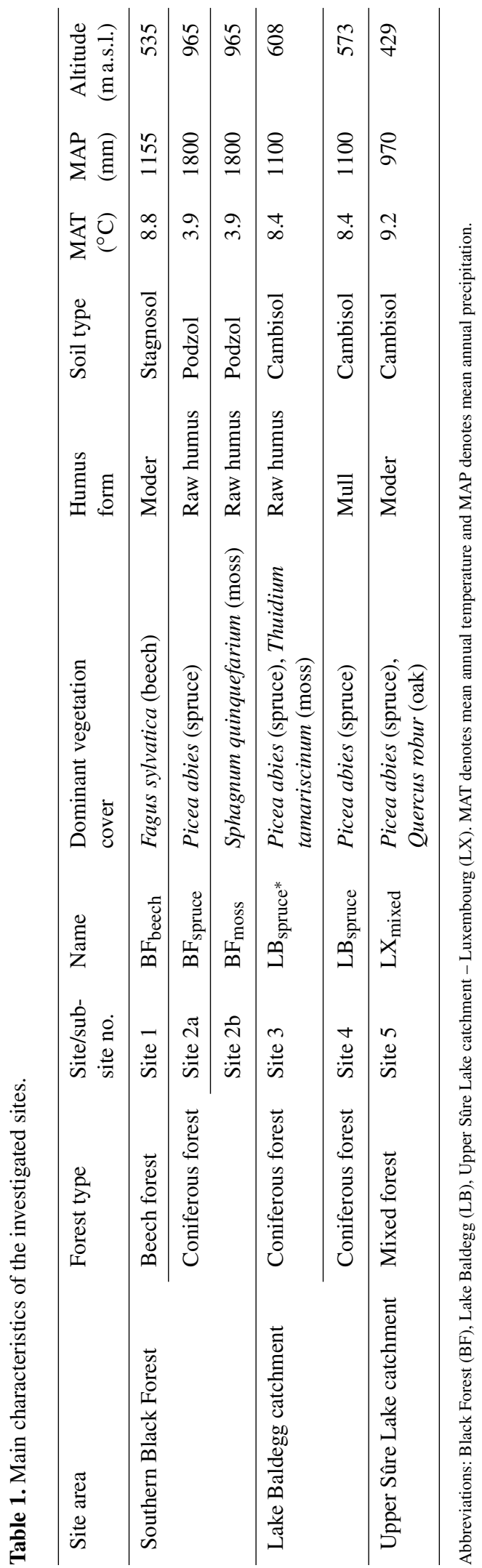

Biogeosciences, 17, 2169-2180, 2020 


\subsection{Particle size separation}

The particle fraction of size $<63 \mu \mathrm{m}$ was separated from four A horizon soil samples collected from various forest types (beech forest (site 1), coniferous forest (site 2a), coniferous forest with moss cover (site 3), and mixed forest (site 5)). Prior to the separation, soil aggregates were disrupted by ultrasonic dispersion using an ultrasonic probe (Branson 250 model, Branson Ultrasonics, Danbury, CT, USA). A $500 \mathrm{~J} \mathrm{~mL}^{-1}$ ultrasonic energy was applied as described in Schmidt et al. (1999). This energy is sufficient for total disruption of aggregates without redistribution and compositional changes in OM. After disruption, the fraction of size $<63 \mu \mathrm{m}$ was separated by wet sieving and water was removed by sedimentation and centrifugation.

\subsection{Total lipid extraction and compound separation}

Powdered samples were extracted using an accelerated solvent extraction system (ASE 350, Dionex Corp., Sunnyvale, CA, USA) with dichloromethane (DCM) / methanol $(\mathrm{MeOH})(9: 1, v / v)$ over three extraction cycles at $100^{\circ} \mathrm{C}$. The total lipid extract (TLE) was volume reduced by vacuum evaporation (Rocket Synergy evaporator, Genevac Ltd., Ipswich, UK). The TLE was subsequently separated into neutral, acidic, and polar fractions by solid-phase extraction using aminopropyl-bonded silica gel as the stationary phase (Jacob et al., 2005). The acidic fraction (including free fatty acids) was methylated at $60^{\circ} \mathrm{C}$ for $1 \mathrm{~h}$ using $1 \mathrm{~mL}$ of $12 \%-$ $14 \%$ boron trifluoride $\left(\mathrm{BF}_{3}\right)$ in $\mathrm{MeOH}$, and fatty acid methyl esters (FAMEs) were extracted with hexane and $0.1 \mathrm{M} \mathrm{KCl}$. The aliphatic hydrocarbons containing long-chain $n$-alkanes were separated from the neutral fraction obtained earlier using a column filled with an activated silica gel by eluting with $n$-heptane.

\subsection{Biomarker analysis}

Individual compounds in the FAMEs and aliphatic hydrocarbon fractions were identified using a TRACE GC Ultra gas chromatograph coupled with a DSQ II mass spectrometer (MS) (Thermo Scientific, Waltham, MA, USA). Quantification was performed using the same GC coupled with a flame ionization detector (FID) (Thermo Scientific, Waltham, MA, USA). The GC method was set to be identical during both measurements as described in Alewell et al. (2016).

\subsection{Compound-specific isotope analysis (CSIA)}

The $\delta^{13} \mathrm{C}$ isotopic composition of individual FAMEs and $n$-alkanes was determined using a Trace $1310 \mathrm{GC}$ with split/splitless injector and FID detector interfaced online via a GC-IsoLink II to a ConFlo IV and Delta V Plus isotope ratio mass spectrometer (Thermo Scientific, Bremen, Germany). A DB-5MS capillary column $(50 \times 0.2 \mathrm{~mm}$ i.d., $0.33 \mu \mathrm{m}$ film thickness, J \& W Scientific, Folsom, CA, USA) was used. The GC temperature programme for $n$-alkanes was $70^{\circ} \mathrm{C}$ (held $4 \mathrm{~min}$ ) to $320^{\circ} \mathrm{C}$ (held $35 \mathrm{~min}$ ) at $5^{\circ} \mathrm{C} \mathrm{min}^{-1}$. The GC temperature programme for FAMEs was $70^{\circ} \mathrm{C}$ (held $4 \mathrm{~min}$ ) to $150^{\circ} \mathrm{C}$ at $20^{\circ} \mathrm{C} \mathrm{min}^{-1}$ and afterwards to $320^{\circ} \mathrm{C}$ (held $40 \mathrm{~min}$ ) at $5^{\circ} \mathrm{C} \mathrm{min}^{-1}$. He (purity grade 5.0) was used as a carrier gas at a constant flow of $1 \mathrm{~mL} \mathrm{~min}^{-1} \cdot \mathrm{CO}_{2}$ of known $\delta^{13} \mathrm{C}$ isotopic composition used as reference gas was automatically introduced via ConFlo IV into the isotope ratio mass spectrometer in a series of five pulses at the beginning and four pulses at the end of each analysis during every measurement. The system was externally calibrated with standard mixtures A6 for $n$-alkanes $\left(n-\mathrm{C}_{16}\right.$ to $\left.n-\mathrm{C}_{30}\right)$ and F83 for FAMEs (even chain fatty acid methyl and ethyl esters from $n-\mathrm{C}_{14: 0}$ to $n-\mathrm{C}_{20: 0}$ ), both obtained from Arndt Schimmelmann, Indiana University, IN, USA. Isotopically certified $n$ - $\mathrm{C}_{24: 0}, n-\mathrm{C}_{30: 0}$ (Arndt Schimmelmann, Indiana University, IN, USA) and $n$ - $\mathrm{C}_{26: 0}, n-\mathrm{C}_{28: 0}$ (Sigma-Aldrich, St. Louis, MO, USA) FAMEs were further added to the F8-3 mixture. The carbon isotope values of samples are reported in delta notation relative to the standard V-PDB, averaging at least three replicate measurements. The analytical uncertainty is lower than $\pm 0.5 \%$. The reported $\delta^{13} \mathrm{C}$ values of FAMEs were corrected for the additional carbon atom introduced during methylation using the following formula:

$\delta^{13} \mathrm{C}_{\mathrm{FA}}=\frac{\delta^{13} \mathrm{C}_{\mathrm{FAME}}-(1-X) \delta^{13} \mathrm{C}_{\text {Methanol }}}{X}$,

where $X$ is the ratio of $\mathrm{C}$ atoms in the $\mathrm{FA}$ to the $\mathrm{C}$ atoms in the corresponding FAME. $\delta^{13} \mathrm{C}_{\text {Methanol was measured with }}$ an elemental analyser coupled to an isotope ratio mass spectrometer (EA-IRMS), using similar instrumental parameters as the bulk $\mathrm{C}$ isotope analysis described above.

\section{Results and discussion}

\subsection{Concentration of biomarkers}

The lipids from fresh leaves as well as $\mathrm{O}$ and $\mathrm{A}$ horizons showed even-over-odd predominance in long-chain fatty acids $\left(>n-\mathrm{C}_{22: 0}\right)$ and odd-over-even predominance in $n$ alkanes $\left(>n-\mathrm{C}_{23}\right)$, a property usually ascribed to the lipids derived from higher plant biomass (Eglinton et al., 1962; Kolattukudy et al., 1976; Amblès et al., 1994a). To quantify this pattern of the chain length preference, carbon preference index (CPI) values were also calculated (Eglinton et al., 1962). Mean CPI values of fatty acids $\left(n-\mathrm{C}_{22: 0-30: 0)}\right.$ and $n$-alkanes $\left(n-\mathrm{C}_{23}-33\right)$ were 5.7 and 5.5 respectively, indicating the input from higher plants. Similar concentrations (relative abundance with regard to total OM) of both of the compound classes were observed between fresh plant biomass and degraded OM, with a slight increase within the $\mathrm{O}$ horizon (Fig. 2). We also defined concentration in mineral soil with regard to total soil OM and not to soil weight for its better comparability to the fresh plant biomass and $\mathrm{O}$ horizon. 


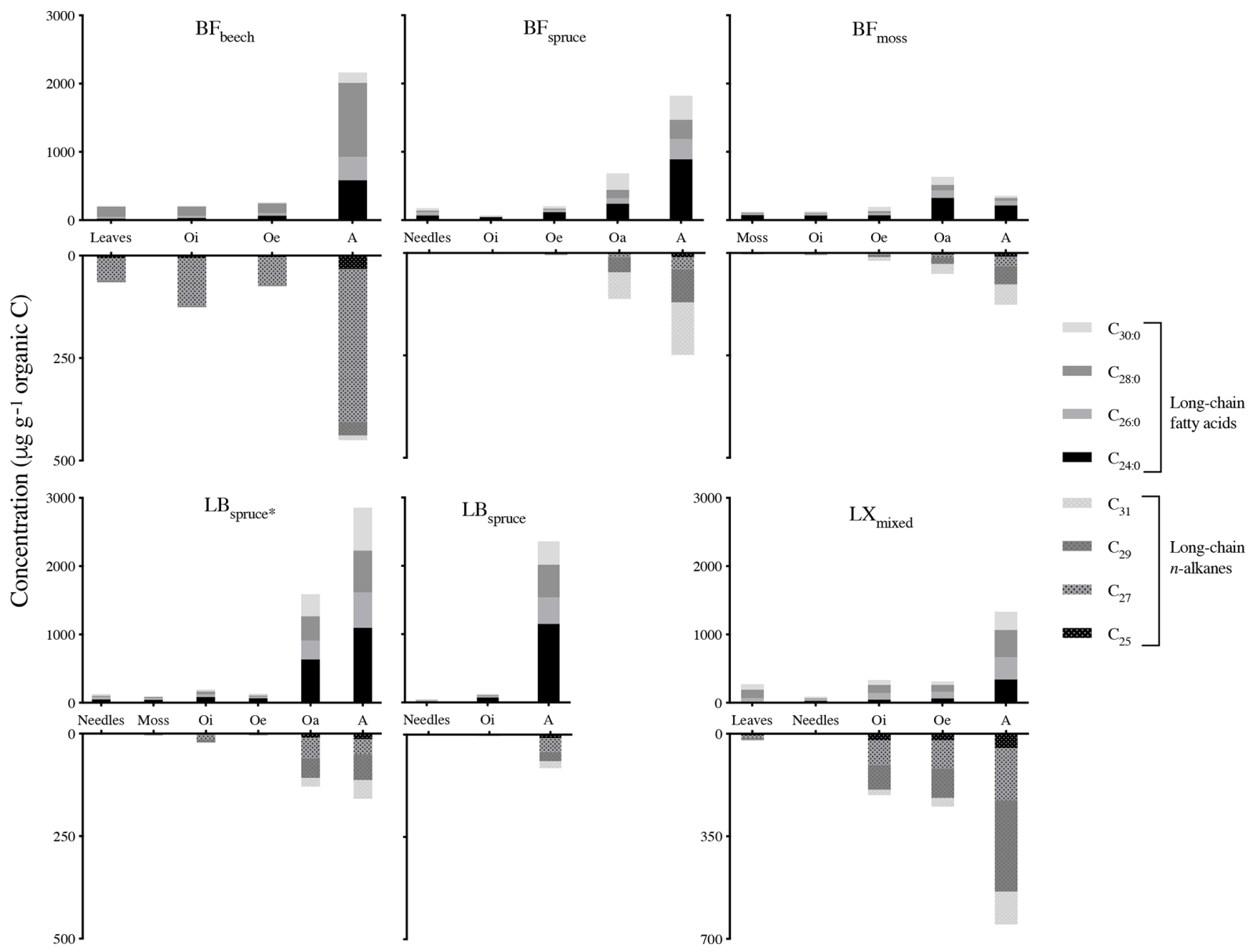

Figure 2. Concentration of long-chain fatty acids and $n$-alkanes in fresh plant biomass and underlying horizons from different sites (note the different scales of fatty acid and $n$-alkane concentration). Abbreviations: Black Forest (BF), Lake Baldegg (LB), Upper Sûre Lake catchment - Luxembourg (LX).

We found a strong increase in compound concentrations in the mineral soils collected from various sites (Fig. 2), except site $\mathrm{BF}_{\text {moss }}$. The strong increase in the concentrations from the $\mathrm{O}$ horizon to mineral soil (A horizon) indicates a preferential preservation of long-chain fatty acids and $n$-alkanes compared to soil bulk OM (Fig. 2). In general, long-chain fatty acids were relatively more abundant than $n$-alkanes in the plant-soil system, similar to previously reported findings (van Bergen et al., 1998; Naafs et al., 2004; Chikaraishi and Naraoka, 2006).

Interspecies variability was recorded by the molecular distribution patterns of the compounds in fresh plant biomass (Fig. S1a and b in the Supplement). The coniferous trees had relatively high concentrations of $n-\mathrm{C}_{29}$ alkane and $n-\mathrm{C}_{24: 0}$ fatty acid. Fresh leaves of broadleaved trees showed relatively high concentrations of $n-\mathrm{C}_{27}$ alkane and $n-\mathrm{C}_{28: 0}$ fatty acid. The sphagnum species were characterized by high $n$ $\mathrm{C}_{23}$ or $n-\mathrm{C}_{21}$ alkane, differing from conifers and broadleaved trees, also consistent with previously reported distribution patterns (Maffei et al., 2004; Bush and McInerney, 2013).
However, molecular distribution patterns observed in fresh plant biomass were not necessarily transferred to the $\mathrm{O}$ and $\mathrm{A}$ horizons (Fig. S1a and b). This was shown by the changes in average chain length (ACL) values of both compound classes (Fig. 3). Relatively higher ACL values of $n$-alkanes in the A horizon compared to overlying horizons from some of the sites might have been the result of preferential degradation of shorter-chained homologues $\left(<n-\mathrm{C}_{27}\right)$ and preservation of longer-chained homologues from $n$ - $\mathrm{C}_{27}$ and higher (Lichtfouse et al., 1998; van Bergen et al., 1998; Marseille et al., 1999). In the case of long-chain fatty acids, changes in the molecular distribution patterns (Fig. S1a) and a decrease in the ACL values (Fig. 3) from fresh matter to the A horizon were observed at most sites. This might be explained by the production of long-chain fatty acids $\left(>n-\mathrm{C}_{20: 0}\right)$ in the $\mathrm{O}$ and A horizons from the oxidation of other components of vegetation-derived lipids such as $n$-alkanes and $n$-alkanols (Amblès et al., 1994a, b; Marseille et al., 1999) and also a contribution of shorter-chained homologues from microor- 


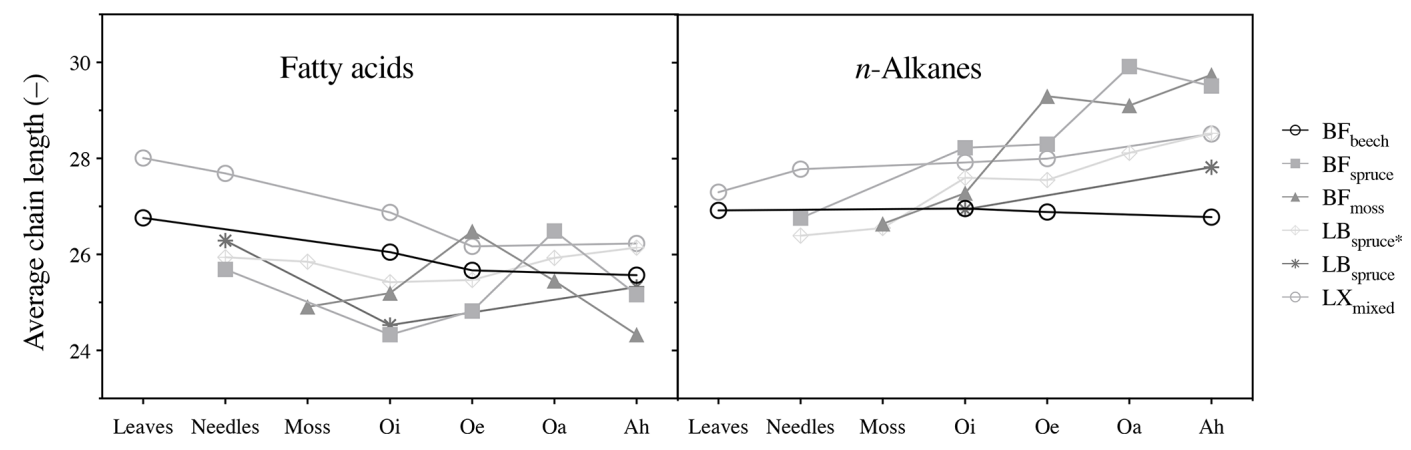

Figure 3. Average chain length (ACL, $\mathrm{C}$ atoms) of fatty acids ( $\left.\mathrm{ACL}_{22-32}\right)$ and $n$-alkanes ( $\left.\mathrm{ACL}_{21-33}\right)$. Abbreviations: $\mathrm{Black}$ Forest (BF), Lake Baldegg (LB), Upper Sûre Lake catchment - Luxembourg (LX).

ganisms (Lichtfouse et al., 1995; Chikaraishi and Naraoka, 2006).

\subsection{Stable carbon isotopic composition ( $\left({ }^{13} \mathrm{C}\right.$ values)}

The bulk stable carbon isotope values were in between $-32.4 \%$ and $-26.1 \%$ o, similar to the typical $\delta^{13} \mathrm{C}$ values of the $\mathrm{C}_{3}$ plant-soil system (Diefendorf et al., 2010). During degradation, the carbon isotopic composition generally showed consecutive enrichment in ${ }^{13} \mathrm{C}$ from fresh plant biomass (leaves, needles, and mosses) via organic horizons to the mineral soil. The $\delta^{13} \mathrm{C}$ increment from fresh plant biomass to the $\mathrm{A}$ horizon varied between $3.5 \%$ o $\left(\mathrm{BF}_{\text {beech }}\right)$ and $5.6 \%$ o $\left(\mathrm{BF}_{\text {moss }}\right)$ (Fig. 4). Selective degradation of bulk OM with depleted carbon isotopic signature has been observed previously, but with fewer significant changes probably related to short timescales (Nguyen Tu et al., 2004). Our findings report consistent degradation (with $p$ value $=0.72$ denoting similar extent of degradation across studied forest systems) as well as consecutive increase in $\delta^{13} \mathrm{C}$ values through degradation stages ( $p$ value $<0.001$ denoting significantly different $\delta^{13} \mathrm{C}$ values). Hence the cautious use of bulk carbon isotope values for using it as source soil signatures is necessary, especially when the vegetation sources found are either $\mathrm{C}_{3}$ or $\mathrm{C}_{4}$ only.

Compared to bulk isotopic composition of fresh plant biomass, compound-specific isotope values of long-chain fatty acids and $n$-alkanes were generally lower by $-3 \%$ o and $-3.7 \%$ respectively (Figs. 4 and 5), in agreement with previous studies (Collister et al., 1994; Huang et al., 1997; Nguyen Tu et al., 2011). The compound-specific $\delta^{13} \mathrm{C}$ values of long-chain fatty acids $\left(n-\mathrm{C}_{24: 0}\right.$ to $\left.n-\mathrm{C}_{30: 0}\right)$ and $n$ alkanes $\left(n-\mathrm{C}_{25}\right.$ to $\left.n-\mathrm{C}_{31}\right)$ showed a general increase in $\delta^{13} \mathrm{C}$ values from fresh plant biomass to the $\mathrm{O}$ horizon overlying the mineral soil (A horizon); however there were only slight or no further changes to the A horizon (Fig. 5, Table 2). Both the compound classes showed similar trends of ${ }^{13} \mathrm{C}$ enrichment at each site. Exceptionally, some $n$-alkane homologues showed a strong enrichment between the $\mathrm{O}$ and A horizons, e.g. $\mathrm{BF}_{\text {moss }}\left(n-\mathrm{C}_{25,27}\right), \mathrm{LB}_{\text {spruce* }}\left(n-\mathrm{C}_{29}\right)$, and $\mathrm{LX}_{\text {mixed }}(n$ -

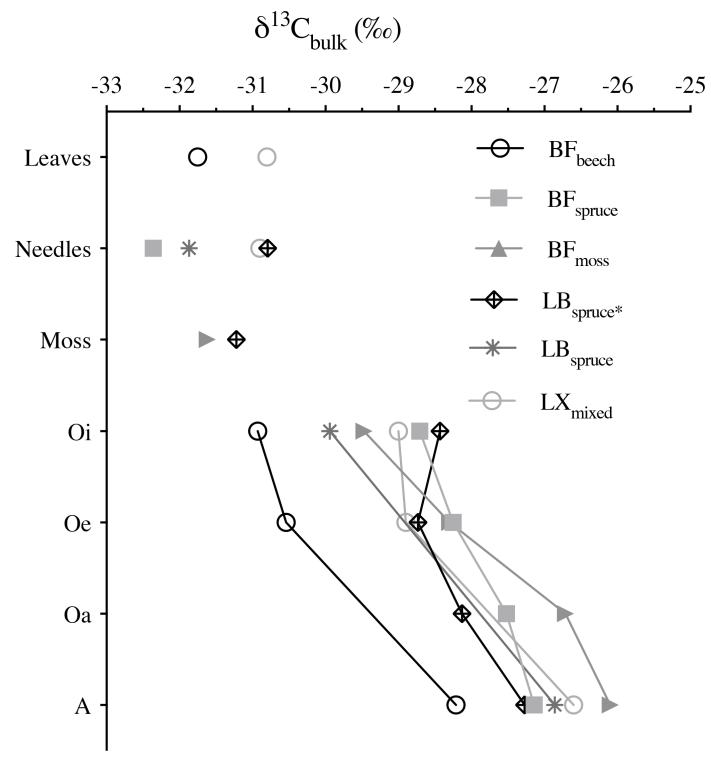

Figure 4. Bulk $\delta^{13} \mathrm{C}$ values (\%o) of fresh plant biomass (leaves, needles, and mosses) and underlying horizons. Abbreviations: Black Forest (BF), Lake Baldegg (LB), Upper Sûre Lake catchment Luxembourg (LX).

$\mathrm{C}_{27,29)}$ sites. Fresh moss material exhibited the lowest $\delta^{13} \mathrm{C}$ values for both the compound classes, $-37.7 \%$ o $\left(n-\mathrm{C}_{26: 0}\right.$ FA) and $-40.4 \%$ ( $n-\mathrm{C}_{25}$ alkane) of Sphagnum quinquefarium $\left(\mathrm{BF}_{\mathrm{moss}}\right)$ and $-39.4 \%$ ( $n$ - $\left.\mathrm{C}_{26: 0} \mathrm{FA}\right)$ and $-37 \%$ (n$\mathrm{C}_{27}$ alkane) of Thuidium tamariscinum ( $\mathrm{LB}_{\text {spruce* }}$ ), similar to previously reported sphagnum $n$-alkane isotope values (Brader et al., 2010). $\delta^{13} \mathrm{C}$ values of mosses are lower as they generally grow in wet and humid conditions and experience less water loss due to evapotranspiration (Sachse et al., 2006). Sites $2 \mathrm{a}\left(\mathrm{BF}_{\text {spruce }}\right)$ and $2 \mathrm{~b}\left(\mathrm{BF}_{\text {moss }}\right)$ are both located in a spruce forest with thick moss cover. Hence the strong isotopic enrichment in $n-\mathrm{C}_{25}$ and $n-\mathrm{C}_{27}$ alkanes $(3.9 \%$ and $2.4 \%$ respectively) observed from the $\mathrm{O}$ horizon to mineral soil (A horizon) at $\mathrm{BF}_{\text {moss }}$ might have been caused by significantly higher long-term input from spruce (with a com- 

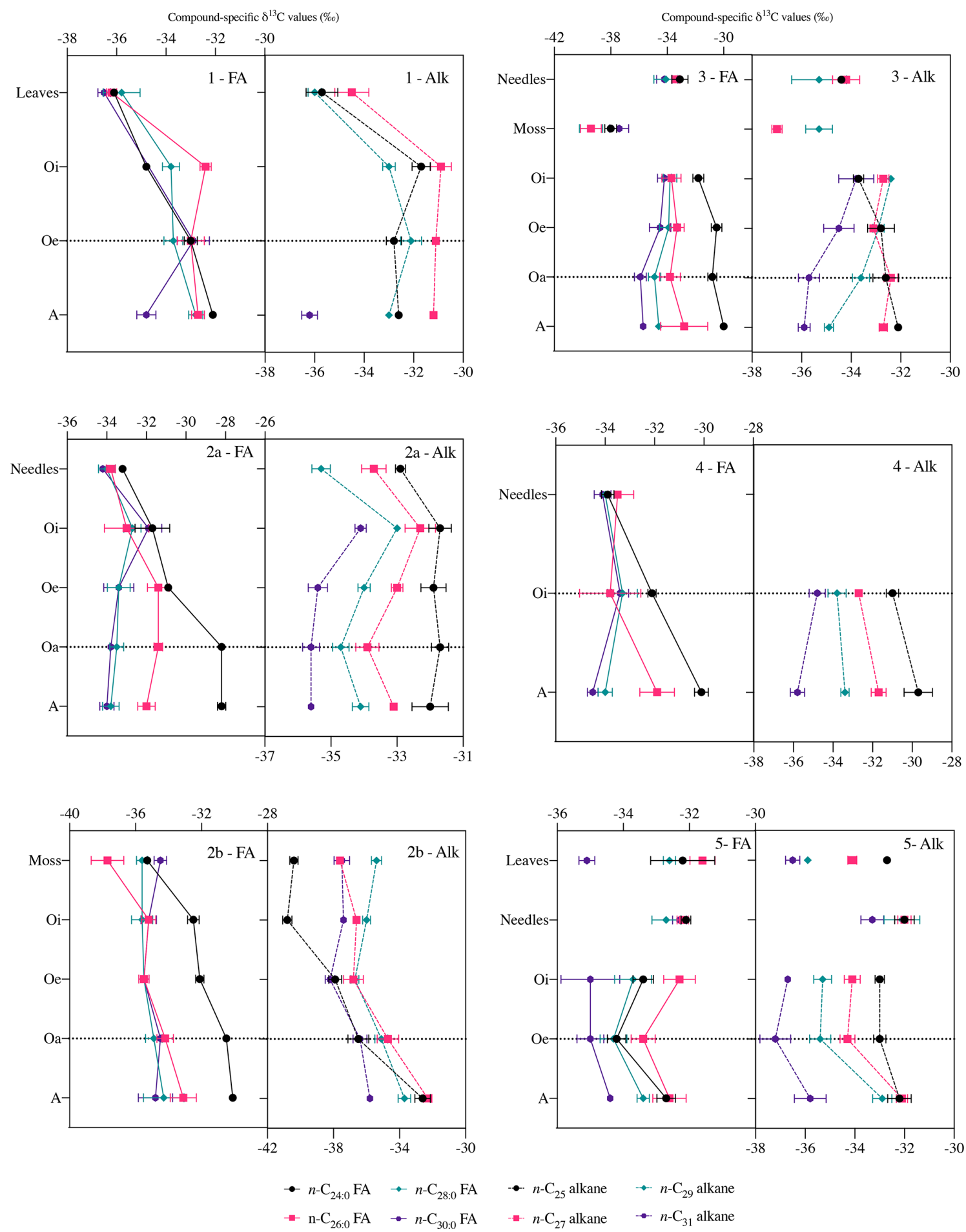

Figure 5. Compound-specific $\delta^{13} \mathrm{C}$ values of long-chain fatty acids ( $n$ - $\mathrm{C}_{24: 0}$ to $n$ - $\left.\mathrm{C}_{30: 0}\right)$ and long-chain $n$-alkanes $\left(n-\mathrm{C}_{25}\right.$ to $n$-C $\left.\mathrm{C}_{31}\right)$ in fresh plant biomass (leaves, needles, and mosses) and across the underlying horizons (mean \pm measurement error of three replicates). Black Forest (beech (1), spruce (2a), moss (2b)), Lake Baldegg (spruce* (3), spruce (4)), Upper Sûre Lake catchment - Luxembourg (mixed forest (5)). Abbreviations: fatty acids (FA); $n$-alkanes (Alk). ${ }^{13} \mathrm{C}$ values generally remained stable after the horizon indicated by a horizontal dotted line. 
Table 2. Range of compound-specific $\delta^{13} \mathrm{C}$ values between the A horizon and fresh plant biomass average $\left(\Delta_{1}\right)$ and between the A horizon and overlying $\mathrm{O}$ horizon $\left(\Delta_{2}\right)$ (significance levels derived from ANOVA or Tukey's honestly significant difference test for the difference in $\delta^{13} \mathrm{C}$ values, given in parentheses).

\begin{tabular}{|c|c|c|c|c|c|c|c|c|c|}
\hline \multirow[t]{2}{*}{ Site name } & \multirow{2}{*}{$\begin{array}{l}\text { Change in } \delta^{13} \mathrm{C} \\
\text { value }(\% \circ)\end{array}$} & \multicolumn{4}{|c|}{ Fatty acids } & \multicolumn{4}{|c|}{ n-Alkanes } \\
\hline & & $n-\mathrm{C}_{24: 0}$ & $n-\mathrm{C}_{26: 0}$ & $n-\mathrm{C}_{28: 0}$ & $n-\mathrm{C}_{30: 0}$ & $n-\mathrm{C}_{25}$ & $n-\mathrm{C}_{27}$ & $n-\mathrm{C}_{29}$ & $n-\mathrm{C}_{31}$ \\
\hline \multirow[t]{2}{*}{$\mathrm{BF}_{\text {beech }}$} & $\Delta_{1}$ & $4.0(* * *)$ & $3.6(* *)$ & $3.0(* *)$ & 1.7 (n.s.) & $3.1(* *)$ & $3.2(* *)$ & $2.9(* *)$ & - \\
\hline & $\Delta_{2}$ & 0.9 (n.s.) & 0.4 (n.s.) & 0.8 (n.s.) & -1.9 (n.s.) & 0.2 (n.s.) & -0.1 (n.s.) & -0.9 (n.s.) & - \\
\hline \multirow{2}{*}{$\mathrm{BF}_{\text {spruce }}$} & $\Delta_{1}$ & $5.0(*)$ & 1.8 (n.s.) & 0.2 (n.s.) & 0.2 (n.s.) & 0.9 (n.s.) & 0.6 (n.s.) & 1.1 (n.s.) & - \\
\hline & $\Delta_{2}$ & 0.0 (n.s.) & -0.7 (n.s.) & -0.3 (n.s.) & -0.2 (n.s.) & -0.3 (n.s.) & 0.8 (n.s.) & 0.5 (n.s.) & - \\
\hline \multirow[t]{2}{*}{$\mathrm{BF}_{\text {moss }}$} & $\Delta_{1}$ & $5.2(*)$ & 4.6 (n.s.) & 1.3 (n.s.) & -0.3 (n.s.) & $7.8(* *)$ & $5.3(*)$ & 1.7 (n.s.) & 1.7 (n.s.) \\
\hline & $\Delta_{2}$ & 0.3 (n.s.) & 1.1 (n.s.) & 0.7 (n.s.) & -0.3 (n.s.) & 3.9 (n.s.) & 2.4 (n.s.) & 1.4 (n.s.) & 0.6 (n.s.) \\
\hline \multirow[t]{2}{*}{$\mathrm{LB}_{\text {spruce* }}$} & $\Delta_{1}$ & 3.1 (n.s.) & 0.6 (n.s.) & -0.5 (n.s.) & -1.5 (n.s.) & 2.3 (n.s.) & 1.6 (n.s.) & 0.5 (n.s.) & - \\
\hline & $\Delta_{2}$ & 0.8 (n.s.) & 1.0 (n.s.) & 0.3 (n.s.) & 0.2 (n.s.) & 0.5 (n.s.) & -0.3 (n.s.) & -1.3 (n.s.) & - \\
\hline \multirow[t]{2}{*}{$\mathrm{LB}_{\text {spruce }}$} & $\Delta_{1}$ & 3.8 (n.s.) & 1.6 (n.s.) & 0.0 (n.s.) & -0.4 (n.s.) & - & - & - & - \\
\hline & $\Delta_{2}$ & 2.0 (n.s.) & 1.9 (n.s.) & -0.7 (n.s.) & -1.1 (n.s.) & 1.3 (n.s.) & 1.0 (n.s.) & 0.4 (n.s.) & -1.0 (n.s.) \\
\hline \multirow{2}{*}{$\mathrm{LX}_{\text {mixed }}$} & $\Delta_{1}$ & -0.5 (n.s.) & -0.7 (n.s.) & -0.8 (n.s.) & -0.7 (n.s.) & 0.2 (n.s.) & 1.0 (n.s.) & 1.1 (n.s.) & -0.9 (n.s.) \\
\hline & $\Delta_{2}$ & 1.5 (n.s.) & 0.8 (n.s.) & 0.9 (n.s.) & 0.6 (n.s.) & 0.8 (n.s.) & $2.2(*)$ & $2.5(* *)$ & 1.4 (n.s.) \\
\hline
\end{tabular}

Significance codes: non-significant ( $p>0.05)$, n.s.; $* p \leq 0.05 ; * * p<0.01 ; * * * p<0.001$. Abbreviations: Black Forest (BF), Lake Baldegg (LB), Upper Sûre Lake catchment Luxembourg (LX).

paratively higher $\delta^{13} \mathrm{C}$ value) compared to the fresh and degraded moss to the mineral soil. However, supportive data of, for example, long-term biomass inputs to soil from different species present at the particular site, were not available. Also, site $\mathrm{LX}_{\text {mixed }}$ has a vegetation cover of two distinct species (Table 1). The difference in isotopic composition of fresh plant biomass of these two species along with its seasonal variability might be a cause of changes in $\delta^{13} \mathrm{C}$ values during degradation. Also, isotopically distinct microbial input of long-chain compounds cannot be excluded (Marseille et al., 1999; Chikaraishi and Naraoka, 2006).

At sites where a single dominant vegetation is present, we observed increase up to $5 \%$ in long-chain fatty acids and up to $3.2 \%$ in long-chain $n$-alkanes from fresh plant biomass to the A horizon, similar to previous findings (Chikaraishi and Naraoka, 2006; Griepentrog et al., 2015, 2016). It was found that most of the degradation effect on isotopic composition took place up to the $\mathrm{O}$ horizon, and slight or no further changes were observed during transfer to the A horizon from the overlying $\mathrm{O}$ horizon. Table 2 summarizes this finding where we compared the changes in compound-specific isotope values with the level of significance. We calculated the magnitude of enrichment or depletion in ${ }^{13} \mathrm{C}$ from the mineral soil horizon with respect to fresh biomass $\left(\Delta_{1}\right)$ and also with respect to the overlying $\mathrm{O}$ horizon $\left(\Delta_{2}\right)$ as follows:

$$
\begin{aligned}
& \Delta_{1}=\delta^{13} \mathrm{C}_{(\text {A horizon })}-\delta^{13} C_{(\text {fresh plant biomass })} \\
& \Delta_{2}=\delta^{13} \mathrm{C}_{(\text {A horizon })}-\delta^{13} \mathrm{C}_{(\text {overlying O horizon })} .
\end{aligned}
$$

For the calculation of $\Delta_{1}$ (Eq. 2), we excluded the $\delta^{13} \mathrm{C}$ values of fresh moss to obtain the $\delta^{13} \mathrm{C}_{\text {(fresh plant biomass) value, }}$ only at site 3 . This was done to eliminate the overestimation of the magnitude of isotopic change, as mosses had considerably low isotope values compared to other fresh materials (Fig. 5).

The bulk $\delta^{13} \mathrm{C}$ values showed a continuous increase from fresh plant material through the degradation stages to the A horizon and did not exhibit the stability needed for use as an isotope tracer. Furthermore, fresh plant biomass generally exhibited a wider range of compound-specific $\delta^{13} \mathrm{C}$ values (7.5\%o for $n-\mathrm{C}_{25}$ alkane and $3.9 \%$ for $n-\mathrm{C}_{26: 0}$ fatty acid) than bulk isotope values $(1.6 \%$ ) across all the sites. Hence in terms of the stability during early degradation in soils and interspecies variability, our results confirm that the compoundspecific isotope analysis is a more useful technique for sediment source attribution, and the analysis should not rely on bulk isotope values.

\subsection{Compound-specific isotopic composition of soil particle size fractions}

We compared the compound-specific $\delta^{13} \mathrm{C}$ values of longchain fatty acids and $n$-alkanes from the bulk soil $(<2 \mathrm{~mm})$ to the fine silt plus clay fraction $(<63 \mu \mathrm{m})$ (Fig. 6). None of the fatty acids showed a significant difference in their $\delta^{13} \mathrm{C}$ values between the two soil particle size fractions. Only for the $\mathrm{LB}_{\text {spruce* }}$ site were $\delta^{13} \mathrm{C}$ values of long-chain fatty acids considerably (up to $2.1 \%$ ) but not significantly different among the studied fractions. Similar results were obtained for long-chain $n$-alkanes, where none of the $n$-alkanes from studied sites differed significantly between the different particle size fractions, with a difference of up to $1 \%$ (Fig. 6). Cayet and Lichtfouse (2001) reported preferential input of 


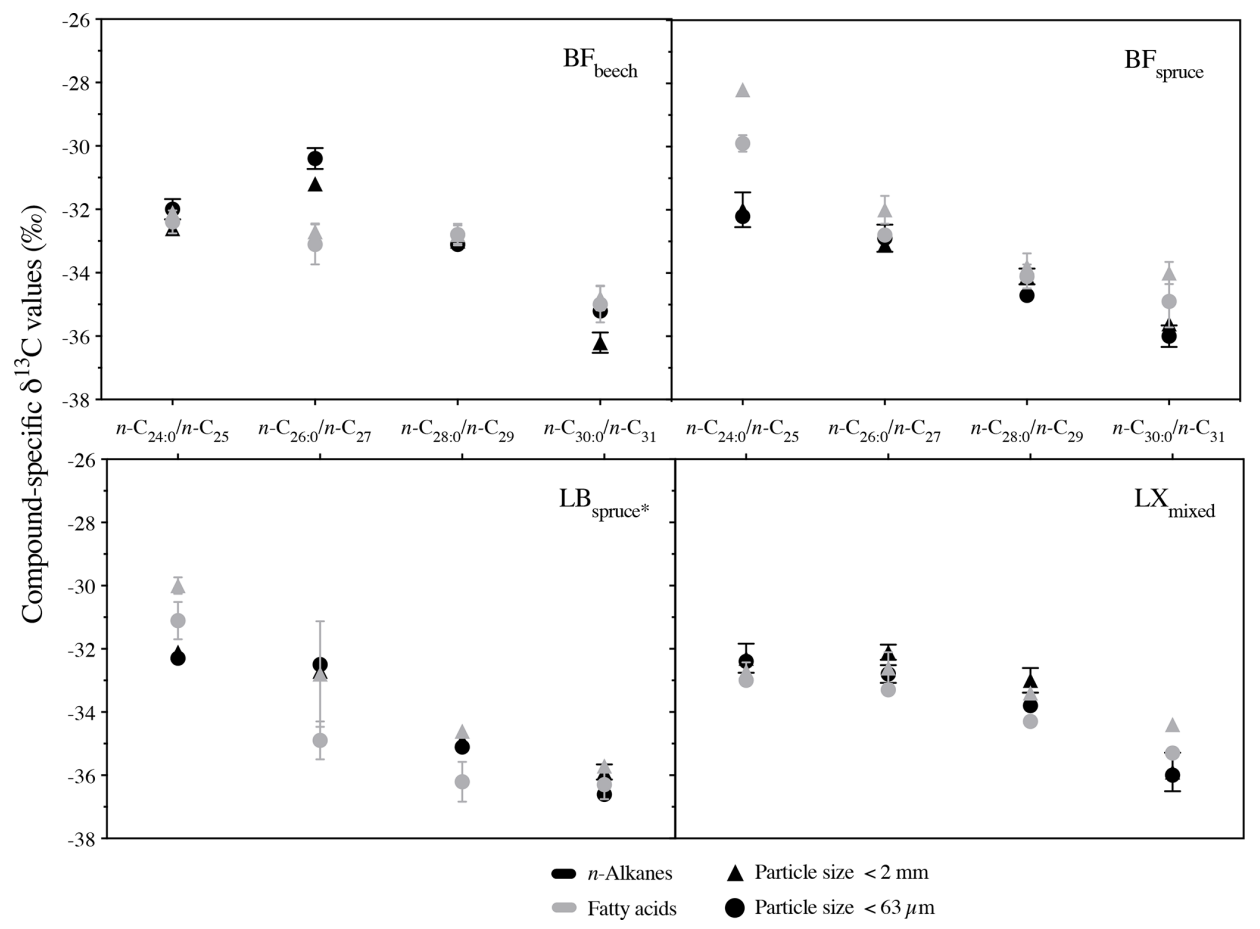

Figure 6. Comparison of compound-specific $\delta^{13} \mathrm{C}$ values from two particle size fractions in soil from four sites (mean \pm measurement error of three replicates). Abbreviations: Black Forest (BF), Lake Baldegg (LB), Upper Sûre Lake catchment - Luxembourg (LX).

long-chain $n$-alkanes in soils via a larger (200-2000 $\mu \mathrm{m})$ particle size fraction. However in terms of isotopic composition of soils, Quénéa et al. (2006) reported a less than $1 \%$ o difference in long-chain $n$-alkanes $\delta^{13} \mathrm{C}$ among the soil size fractions. In accordance with previous findings on $n$-alkanes, our results simultaneously studying long-chain fatty acids and $n$ alkanes confirm that the compound-specific carbon isotope values of both compound classes were not significantly different between the two particle sizes. Long-chain $n$-alkanes were found to be even less prone to the isotopic fractionation within the soil particle size fractions. These results indicate that the analysis of bulk soil material instead of the fine soil fraction $(<63 \mu \mathrm{m})$ might be suitable for sediment source attribution from soils to freshwater systems, which might not only increase work and cost effectiveness of the method but also reduce potential error sources due to particle size fractionation effects. In general, the results above further strengthen the necessary requirement of conservativeness of tracer signature during erosion processes like detachment, dispersion, and sediment transport, for CSIA-based sediment source apportionment.

\section{Conclusions}

We tested the potential stability of compound-specific carbon isotope values of long-chain fatty acid and $n$-alkanes during early degradation in the soil, usually employed as tracers in a sediment source fingerprinting technique based on compound-specific isotope analysis. We assumed that the potential stability of a tracer signature during degradation stages from fresh plant material to the mineral soil might indicate its suitability for detachment and transport processes during soil erosion. We determined a clear increase in $\delta^{13} \mathrm{C}$ values for both compound classes from above-ground plant biomass to the $\mathrm{O}$ horizon overlaying the mineral soil (A horizon); however only slight or no further changes were observed between the $\mathrm{O}$ and $\mathrm{A}$ horizons. The latter was in clear contrast to bulk $\delta^{13} \mathrm{C}$ values, which continued to become enriched in ${ }^{13} \mathrm{C}$ through all degradation stages from fresh plant biomass to mineral soil (A horizon).

We conclude that this finding emphasizes the suitability of compound-specific isotope analysis compared to the bulk $\delta^{13} \mathrm{C}$ analysis for sediment fingerprinting source attribution using stable carbon isotope. The finding was consistent through the various forest types with different vegetation and humus forms studied. The degree of variability in compoundspecific carbon isotopic signatures in the plant-soil system was mostly similar between both compound classes (longchain fatty acids and $n$-alkanes). Beyond sediment source attribution, this study also suggests necessity for careful evaluation of bulk and compound-specific isotope values for reconstruction of past $\mathrm{C}_{3}-\mathrm{C}_{4}$ vegetation changes in soils. Comparing the tracer signatures between bulk soil material and the fine soil particle size fraction $(<63 \mu \mathrm{m})$, the long-chain $n$-alkanes were found to be less prone to the particle-sizedependent isotopic fractionation than fatty acids. However 
none of the compounds showed significant differences between studied particle sizes. Hence, we suggest that our results indicate that the bulk soil $(<2 \mathrm{~mm})$ can be safely used to determine tracer signatures in CSIA-based sediment source fingerprinting, irrespective of the particle size of sediments collected. This is particularly important as isotope values could also be considered to be not affected by the particle size sorting during sediment transport in a stream. The 10 -fold higher concentrations of the long-chain fatty acids compared to $n$-alkanes in surface soils suggest a better analytical certainty in extraction and measurements of fatty acids in soils and sediments with low lipid content, but the joint investigation of fatty acids and $n$-alkanes would add an additional component in CSIA-based sediment source fingerprinting, and thus more robust results can be expected if an analytically reliable quantity of $n$-alkanes is extracted from samples.

Data availability. Data from isotopic and molecular measurements are available at https://doi.org/10.5281/zenodo.3228446 (Hirave et al., 2019).

Supplement. The supplement related to this article is available online at: https://doi.org/10.5194/bg-17-2169-2020-supplement.

Author contributions. PH helped in designing the study; carried out the sampling, lab work, biomarker quantification, and isotope analyses; evaluated data; and wrote the manuscript. GLBW assisted in analytical method development, isotope analyses, data evaluation, and interpretation and contributed to the writing. AB provided support for isotope analyses and data interpretation and contributed to the writing. CA primarily conceptualized the study, provided support for sampling and data interpretation, and contributed to the writing.

Competing interests. The authors declare that they have no conflict of interest.

Acknowledgements. We thank Marlène Lavrieux for her support in sampling and Thomas Kuhn, from University of Basel, for his assistance in isotope measurements.

Review statement. This paper was edited by Aninda Mazumdar and reviewed by two anonymous referees.

\section{References}

Alewell, C., Birkholz, A., Meusburger, K., Schindler Wildhaber, Y., and Mabit, L.: Quantitative sediment source attribution with compound-specific isotope analysis in a $\mathrm{C}_{3}$ plant-dominated catchment (central Switzerland), Biogeosciences, 13, 15871596, https://doi.org/10.5194/bg-13-1587-2016, 2016.

Amblès, A., Jambu, P., Parlanti, E., Joffre, J., and Riffe, C.: Incorporation of natural monoacids from plant residues into an hydromorphic forest podzol, Eur. J. Soil Sci., 45, 175-182, https://doi.org/10.1111/j.1365-2389.1994.tb00499.x, 1994a.

Amblès, A., Parlanti, E., Jambu, P., Mayoungou, P., and Jacquesy, J.-C.: $n$-Alkane oxidation in soil, Formation of internal monoalkenes, Geoderma, 64, 111-124, https://doi.org/10.1016/0016-7061(94)90092-2, 1994b.

Blake, W. H., Ficken, K. J., Taylor, P., Russell, M. A., and Walling, D. E.: Tracing crop-specific sediment sources in agricultural catchments, Geomorphology, 139-140, 322-329, https://doi.org/10.1016/j.geomorph.2011.10.036, 2012.

Blessing, M., Jochmann, M. A., and Schmidt, T. C.: Pitfalls in compound-specific isotope analysis of environmental samples, Anal. Bioanal. Chem., 390, 591-603, https://doi.org/10.1007/s00216-007-1588-1, 2008.

Brader, A. V., van Winden, J. F., Bohncke, S. J. P., Beets, C. J., Reichart, G.-J., and de Leeuw, J. W.: Fractionation of hydrogen, oxygen and carbon isotopes in $n$-alkanes and cellulose of three Sphagnum species, Org. Geochem., 41, 1277-1284, https://doi.org/10.1016/j.orggeochem.2010.09.006, 2010.

Brandt, C., Cadisch, G., Nguyen, L. T., Vien, T. D., and Rasche, F.: Compound-specific $\delta^{13} \mathrm{C}$ isotopes and Bayesian inference for erosion estimates under different land use in Vietnam, Geoderma Reg., 7, 311-322, https://doi.org/10.1016/j.geodrs.2016.06.001, 2016.

Bush, R. T. and McInerney, F. A.: Leaf wax $n$-alkane distributions in and across modern plants: Implications for paleoecology and chemotaxonomy, Geochim. Cosmochim. Ac., 117, 161-179, https://doi.org/10.1016/j.gca.2013.04.016, 2013.

Canuel, E. A., Freeman, K. H., and Wakeham, S. G.: Isotopic compositions of lipid biomarker compounds in estuarine plants and surface sediments, Limnol. Oceanogr., 42, 1570-1583, https://doi.org/10.4319/lo.1997.42.7.1570, 1997.

Cayet, C. and Lichtfouse, E.: $\delta^{13} \mathrm{C}$ of plant-derived $n$-alkanes in soil particle-size fractions, Org. Geochem., 32, 253-258, https://doi.org/10.1016/S0146-6380(00)00172-8, 2001.

Chen, F., Fang, N., and Shi, Z.: Using biomarkers as fingerprint properties to identify sediment sources in a small catchment, Sci. Total Environ., 557-558, 123-133, https://doi.org/10.1016/j.scitotenv.2016.03.028, 2016.

Chikaraishi, Y. and Naraoka, H.: Carbon and hydrogen isotope variation of plant biomarkers in a plant-soil system, Chem. Geol., 231, 190-202, https://doi.org/10.1016/j.chemgeo.2006.01.026, 2006.

Collister, J. W., Rieley, G., Stern, B., Eglinton, G., and Fry, B.: Compound-specific $\delta^{13} \mathrm{C}$ analyses of leaf lipids from plants with differing carbon dioxide metabolisms, Org. Geochem., 21, 619627, https://doi.org/10.1016/0146-6380(94)90008-6, 1994.

Cooper, R. J., Pedentchouk, N., Hiscock, K. M., Disdle, P., Krueger, T., and Rawlins, B. G.: Apportioning sources of organic matter in streambed sediments: An integrated molecular and compoundspecific stable isotope approach, Sci. Total Environ., 520, 187197, https://doi.org/10.1016/j.scitotenv.2015.03.058, 2015.

Diefendorf, A. F., Mueller, K. E., Wing, S. L., Koch, P. L., and Freeman, K. H.: Global patterns in leaf ${ }^{13} \mathrm{C}$ discrimination and implications for studies of past and fu- 
ture climate, P. Natl. Acad. Sci. USA, 107, 5738-5743, https://doi.org/10.1073/pnas.0910513107, 2010.

Eglinton, G., Gonzalez, A. G., Hamilton, R. J., and Raphael, R. A.: Hydrocarbon constituents of the wax coatings of plant leaves: A taxonomic survey, Phytochemistry, 1, 89-102, https://doi.org/10.1016/S0031-9422(00)88006-1, 1962.

Eglinton, T. I. and Eglinton, G.: Molecular proxies for paleoclimatology, Earth Planet. Sc. Lett., 275, 1-16, https://doi.org/10.1016/j.epsl.2008.07.012, 2008.

Ficken, K. J., Barber, K. E., and Eglinton, G.: Lipid biomarker, $\delta^{13} \mathrm{C}$ and plant macrofossil stratigraphy of a Scottish montane peat bog over the last two millennia, Org. Geochem., 28, 217-237, https://doi.org/10.1016/S0146-6380(97)00126-5, 1998.

Galy, V., Eglinton, T., France-Lanord, C., and Sylva, S.: The provenance of vegetation and environmental signatures encoded in vascular plant biomarkers carried by the GangesBrahmaputra rivers, Earth Planet. Sc. Lett., 304, 1-12, https://doi.org/10.1016/j.epsl.2011.02.003, 2011.

Gibbs, M. M.: Identifying Source Soils in Contemporary Estuarine Sediments: A New Compound-Specific Isotope Method, Estuaries Coasts, 31, 344-359, https://doi.org/10.1007/s12237-0079012-9, 2008.

Glaser, B.: Compound-specific stable-isotope $\left(\delta^{13} \mathrm{C}\right)$ analysis in soil science, J. Plant Nutr. Soil Sc., 168, 633-648, https://doi.org/10.1002/jpln.200521794, 2005.

Glaser, B. and Zech, W.: Reconstruction of climate and landscape changes in a high mountain lake catchment in the Gorkha Himal, Nepal during the Late Glacial and Holocene as deduced from radiocarbon and compound-specific stable isotope analysis of terrestrial, aquatic and microbial biomarkers, Org. Geochem., 36, 1086-1098, https://doi.org/10.1016/j.orggeochem.2005.01.015, 2005.

Griepentrog, M., Eglinton, T. I., Hagedorn, F., Schmidt, M. W. I., and Wiesenberg, G. L. B.: Interactive effects of elevated $\mathrm{CO}_{2}$ and nitrogen deposition on fatty acid molecular and isotope composition of above- and belowground tree biomass and forest soil fractions, Glob. Change Biol., 21, 473-486, https://doi.org/10.1111/gcb.12666, 2015.

Griepentrog, M., Bodé, S., Boeckx, P., and Wiesenberg, G. L. B.: The fate of plant wax lipids in a model forest ecosystem under elevated $\mathrm{CO}_{2}$ concentration and increased nitrogen deposition, Org. Geochem., 98, 131-140, https://doi.org/10.1016/j.orggeochem.2016.05.005, 2016.

Hancock, G. J. and Revill, A. T.: Erosion source discrimination in a rural Australian catchment using compoundspecific isotope analysis (CSIA), Hydrol. Process., 27, 923-932, https://doi.org/10.1002/hyp.9466, 2013.

Hirave, P., Wiesenberg, G. L. B., Birkholz, A., and Alewell, C.: Data from isotopic and molecular measurements for: Understanding the effects of early degradation on isotopic tracers: implications for sediment source attribution using compound-specific isotope analysis (CSIA), Zenodo, https://doi.org/10.5281/zenodo.3228446, 2019.

Huang, Y., Eglinton, G., Ineson, P., Latter, P. M., Bol, R., and Harkness, D. D.: Absence of carbon isotope fractionation of individual $n$-alkanes in a 23 -year field decomposition experiment with Calluna vulgaris, Org. Geochem., 26, 497-501, https://doi.org/10.1016/S0146-6380(97)00027-2, 1997.
Jacob, J., Disnar, J.-R., Boussafir, M., Spadano Albuquerque, A. L., Sifeddine, A., and Turcq, B.: Pentacyclic triterpene methyl ethers in recent lacustrine sediments (Lagoa do Caçó, Brazil), Org. Geochem., 36, 449-461, https://doi.org/10.1016/j.orggeochem.2004.09.005, 2005.

Jansen, B. and Wiesenberg, G. L. B.: Opportunities and limitations related to the application of plant-derived lipid molecular proxies in soil science, SOIL, 3(4), 211-234, https://doi.org/10.5194/soil-3-211-2017, 2017.

Kolattukudy, P. E., Croteau, R., and Buckner, J. S.: Biochemistry of plant waxes, edited by: Kolattukudy, P. E., Chemistry and Biochemistry of Natural Waxes, Elsevier, Amsterdam, 289-347, 1976.

Lavrieux, M., Birkholz, A., Meusburger, K., Wiesenberg, G. L. B., Gilli, A., Stamm, C., and Alewell, C.: Plants or bacteria? 130 years of mixed imprints in Lake Baldegg sediments (Switzerland), as revealed by compound-specific isotope analysis (CSIA) and biomarker analysis, Biogeosciences, 16, 2131-2146, https://doi.org/10.5194/bg-16-2131-2019, 2019.

Lichtfouse, É., Berthier, G., Houot, S., Barriuso, E., Bergheaud, V., and Vallaeys, T.: Stable carbon isotope evidence for the microbial origin of $\mathrm{C}_{14}-\mathrm{C}_{18} n$-alkanoic acids in soils, Org. Geochem., 23, 849-852, https://doi.org/10.1016/0146-6380(95)80006-D, 1995.

Lichtfouse, É., Chenu, C., Baudin, F., Leblond, C., Da Silva, M., Behar, F., Derenne, S., Largeau, C., Wehrung, P., and Albrecht, P.: A novel pathway of soil organic matter formation by selective preservation of resistant straight-chain biopolymers: chemical and isotope evidence, Org. Geochem., 28, 411-415, https://doi.org/10.1016/S0146-6380(98)00005-9, 1998.

Mabit, L., Gibbs, M., Mbaye, M., Meusburger, K., Toloza, A., Resch, C., Klik, A., Swales, A., and Alewell, C.: Novel application of Compound Specific Stable Isotope (CSSI) techniques to investigate on-site sediment origins across arable fields, Geoderma, 316, 19-26, https://doi.org/10.1016/j.geoderma.2017.12.008, 2018.

Maffei, M., Badino, S., and Bossi, S.: Chemotaxonomic significance of leaf wax $n$-alkanes in the Pinales (Coniferales), J. Biol. Res., 1, 3-19, 2004.

Marseille, F., Disnar, J. R., Guillet, B., and Noack, Y.: nAlkanes and free fatty acids in humus and A1 horizons of soils under beech, spruce and grass in the MassifCentral (Mont-Lozère), France, Eur. J. Soil Sci., 50, 433-441, https://doi.org/10.1046/j.1365-2389.1999.00243.x, 1999.

Naafs, D. F. W., Bergen, P. F. V., Jong, M. A. D., Oonincx, A., and Leeuw, J. W. D.: Total lipid extracts from characteristic soil horizons in a podzol profile, Eur. J. Soil Sci., 55, 657-669, https://doi.org/10.1111/j.1365-2389.2004.00633.x, 2004.

Nguyen Tu, T. T., Derenne, S., Largeau, C., Bardoux, G., and Mariotti, A.: Diagenesis effects on specific carbon isotope composition of plant $n$-alkanes, Org. Geochem., 35, 317-329, https://doi.org/10.1016/j.orggeochem.2003.10.012, 2004.

Nguyen Tu, T. T., Egasse, C., Zeller, B., Bardoux, G., Biron, P., Ponge, J.-F., David, B., and Derenne, S.: Early degradation of plant alkanes in soils: A litterbag experiment using ${ }^{13} \mathrm{C}$-labelled leaves, Soil Biol. Biochem., 43, 2222-2228, https://doi.org/10.1016/j.soilbio.2011.07.009, 2011.

Quénéa, K., Largeau, C., Derenne, S., Spaccini, R., Bardoux, G., and Mariotti, A.: Molecular and isotopic study of lipids in particle size fractions of a sandy cultivated soil (Cestas cultiva- 
tion sequence, southwest France): Sources, degradation, and comparison with Cestas forest soil, Org. Geochem., 37, 20-44, https://doi.org/10.1016/j.orggeochem.2005.08.021, 2006.

Reiffarth, D. G., Petticrew, E. L., Owens, P. N., and Lobb, D. A.: Sources of variability in fatty acid (FA) biomarkers in the application of compound-specific stable isotopes (CSSIs) to soil and sediment fingerprinting and tracing: A review, Sci. Total Environ., 565, 8-27, https://doi.org/10.1016/j.scitotenv.2016.04.137, 2016.

Sachse, D., Radke, J., and Gleixner, G.: $\delta \mathrm{D}$ values of individual $n$-alkanes from terrestrial plants along a climatic gradient - Implications for the sedimentary biomarker record, Org. Geochem., 37, 469-483, https://doi.org/10.1016/j.orggeochem.2005.12.003, 2006.

Scharlemann, J. P., Tanner, E. V., Hiederer, R., and Kapos, V.: Global soil carbon: understanding and managing the largest terrestrial carbon pool, Carbon Manag., 5, 81-91, https://doi.org/10.4155/cmt.13.77, 2014.

Schmidt, M. W. I., Rumpel, C., and Kögel-Knabner, I.: Evaluation of an ultrasonic dispersion procedure to isolate primary organomineral complexes from soils, Eur. J. Soil Sci., 50, 8794, https://doi.org/10.1046/j.1365-2389.1999.00211.x, 1999.

Schmidt, M. W. I., Torn, M. S., Abiven, S., Dittmar, T., Guggenberger, G., Janssens, I. A., Kleber, M., Kögel-Knabner, I., Lehmann, J., Manning, D. A. C., Nannipieri, P., Rasse, D. P., Weiner, S., and Trumbore, S. E.: Persistence of soil organic matter as an ecosystem property, Nature, 478, 49-56, https://doi.org/10.1038/nature10386, 2011.

Seki, O., Nakatsuka, T., Shibata, H., and Kawamura, K.: A compound-specific $n$-alkane $\delta^{13} \mathrm{C}$ and $\delta \mathrm{D}$ approach for assessing source and delivery processes of terrestrial organic matter within a forested watershed in northern Japan, Geochim. Cosmochim. Ac., 74, 599-613, https://doi.org/10.1016/j.gca.2009.10.025, 2010. van Bergen, P. F., Nott, C. J., Bull, I. D., Poulton, P. R., and Evershed, R. P.: Organic geochemical studies of soils from the Rothamsted Classical Experiments - IV. Preliminary results from a study of the effect of soil $\mathrm{pH}$ on organic matter decay, Org. Geochem., 29, 1779-1795, https://doi.org/10.1016/S01466380(98)00188-0, 1998.

Upadhayay, H. R., Bodé, S., Griepentrog, M., Huygens, D., Bajracharya, R. M., Blake, W. H., Dercon, G., Mabit, L., Gibbs, M., Semmens, B. X., Stock, B. C., Cornelis, W., and Boeckx, P.: Methodological perspectives on the application of compound-specific stable isotope fingerprinting for sediment source apportionment, J. Soils Sediments, 17, 1537-1553, https://doi.org/10.1007/s11368-017-1706-4, 2017.

Wiesenberg, G. L. B., Schwarzbauer, J., Schmidt, M. W. I., and Schwark, L.: Source and turnover of organic matter in agricultural soils derived from $n$-alkane $/ n$-carboxylic acid compositions and C-isotope signatures, Org. Geochem., 35, 1371-1393, https://doi.org/10.1016/j.orggeochem.2004.03.009, 2004.

Zocatelli, R., Lavrieux, M., Disnar, J.-R., Milbeau, C. L., Jacob, J., and Bréheret, J. G.: Free fatty acids in Lake Aydat catchment soils (French Massif Central): sources, distributions and potential use as sediment biomarkers, J. Soils Sediments, 12, 734-748, https://doi.org/10.1007/s11368-012-0505-1, 2012. 